\title{
Not just another crapshoot development: the challenges and opportunities of modelling after Las Vegas and Macao as an economic development strategy in the $21 \mathrm{st}$ century
}

Paul Vinod Khiatani ${ }^{*}$

\section{${ }^{*}$ Correspondence:}

founderstar@hotmail.com Department of Applied Social Sciences, City University of Hong Kong, 83 Tat Chee Ave, Kowloon, Hong Kong

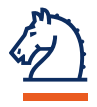

\begin{abstract}
Recent decades highlight an extraordinary growth of casino gambling all over the world. In the race to build casino-cities, particularly to reap economic and social benefits, most aspirers look to replicate the development models of the most famous casino-cities known to date, Las Vegas and Macao. Countries that have modelled after the aforementioned casino-cities have had mix results of success; e.g., Singapore, which followed Macao, yielded considerable success, while other states of the US which modelled Las Vegas, such as Atlantic City, did not have as much luck. In this respect, the countries adhere to the words of the wise; "Standing on the shoulders of the giants". Yet, perhaps explaining why no country can really replicate the successful development experiences of Las Vegas and Macao, most countries fail to see beyond the glitz and glamor to recognize the key challenges and opportunities that helped make Las Vegas and Macao; e.g., with respect to the presence of domestic organized crime groups. This paper delves deep into identifying the key actors and circumstances that made the aforementioned cities what they are today, elucidating the integral development strategies used during their formative years. Utilizing a Marxian approach to understanding the state and state-civil society relations, the paper elucidates why no country can really replicate the development models of Las Vegas and Macao without appreciating its socio-political characteristics and the intricate ties between the upperworld and underworld during their formative years. In light of the findings, recommendations are provided for future research and pragmatic endeavours.
\end{abstract}

Keywords: Casino development, Macao, Las Vegas, State-crime ties, Non-state actors, State actors, Instrumentalist theory, South-south cooperation, Intelligence liaison

\section{Background}

In the last 25 years, the world has seen more casino developments among aspiring countries than any point in history. From Africa, to Europe, to the North, South, and Central America, to Asia, and even Oceania, aspiring nation-states have sought to tap into the potential of casino gambling for industry diversification, urban redevelopment,

(c) 2015 Khiatani. This article is distributed under the terms of the Creative Commons Attribution 4.0 International License (http:// creativecommons.org/licenses/by/4.0/), which permits unrestricted use, distribution, and reproduction in any medium, provided you give appropriate credit to the original author(s) and the source, provide a link to the Creative Commons license, and indicate if changes were made. 
and mass job provisions for citizens (Global Market Advisors 2015). As a tool for economic development, casino gambling, or casino gaming as it is commonly referred to now, has always been somewhat of an elusive option for economic development; one which beckons addressing concerns of morals, well-being, national image, and religion. Yet, as the last 25 years have shown, casino developments have been rampant, both with its successes and failures among aspirers from the Global North and Global South. One common factor among all though, i.e., those who have developed casino-resorts and/or those who aspire to develop casino-resorts, is their reference to the 'proof of concept' for justifying the benefits accrued from casino-resort developments; that is, when lionizing the benefits of casino gaming and integrated resorts for economic development and entertaining the prospects of attaining such promises through developing casino-cities, the countries participating in the "new global race to become 'world-class' tourist and business centers" (Fu and Murray 2014, p. 843) often reference, if not even model after, Las Vegas and Macao.

\section{Las Vegas and Macao: proof of concept for becoming a 'world-class city'}

In the mid-to-late 20th century, the world witnessed unprecedented growth from two lands distant from one another; one in the East, located near Mainland China, and the other in the West, a Midwest state in the United States. Before this, both lands were struggling financially as one suffered from vicious cycles of economic crises (Pina-Cabral 2002) and the other was a barren land, waiting for intervention from the federal government or some 'miracle' worker (Gottdiener et al. 1999). Moreover, both lands had a prominent presence of organized crime groups and street gangs (Gottdiener et al. 1999; Gunn 1995), who brought along with themselves relentless capacity for violence and other crimes. The political authorities, suffering from a limited statehood, of the two lands had no clear agenda for socio-economic development and the two lands remained institutionally underdeveloped, unattractive for foreign investment, and lagging behind the world's advancement.

Despite how bleak the situation seemed for these two economic 'boom-crisis' cycle, gang-infested lands, however, they underwent a historic transformation; from backwater and barren, unattractive lands to world-renowned and celebrated casino-driven capitalist societies in 40 years-time.

Looking at the historical development of Las Vegas and Macao, it is clear that casino development projects promise great benefits for sustained socioeconomic and community development. Casino gaming ventures provide tax revenues for the government, jobs for the civil society, and acts as a secondary economic driver by stimulating commercial activity and infrastructure development around casino gaming (Global Market Advisors 2015; Rephann et al. 1997). This all, in turn, helps with community development and puts the casino-city on the forefront of tourism bulletins, hailed for its vibrancy and entertainment value.

Yet, especially among those that look to Las Vegas and Macao as the ideal model for casino development, the mass proliferation of casino gambling around the world will always fall short of replicating the exact successes of Las Vegas and Macao. According to Thompson (1998), in talking about Las Vegas, the odds of replicating such a marvel is likened to the odds of hitting a ten spot in Keno; that is, 8,911,700-1 (Vlcek 2015). 
The claim, however, lacked reference to historical contexts or factors underpinning the development of the two casino-cities through a historical perspective. Thus, how did Las Vegas and Macao get to be what it is today, who made this possible, and how?

\section{Morris Dalitz and Stanley Ho: kings of their 'gaming empires'}

Miraculous as the transformation of Las Vegas and Macao may seem, it was not due to providence or chance. Rather, upon perusal of search results for the likely 'historymaker', the glory for transforming the cities goes to two businessmen-Mr. Morris 'Barney' Dalitz, also known as Moe Dalitz, for Las Vegas during the 1940s-1980s and Dr. Stanley Ho Hung Sun for Macao during the 1960s-2000s. These two businessmen, despite not having any advanced degrees in Developmental Economics or Casino Management, were able to be the 'savior' the lands needed when the states and economic elites failed to find enduring economic solutions as they succeeded in promoting economic and social growth for the two lands. They were lauded with honorary titles and distinctions, often labeled as 'King' of their respective territories, both locally and internationally. However, upon a closer look, it becomes apparent that these two men were not 'stand-up' figures in society. During the nascent stages of development of the two gambling hubs, rumors and allegations that the two men had ties (and used those ties) to organized crime groups and criminal outfits surfaced. The same men who had ties to the government and statesmen and businessmen in their respective territory also had ties to organized criminal groups and outlaws. Thus, raises a puzzling question that builds on the initial inquiry: Who were these 'connected' men and how did they transform the cities with ties to the underworld and mainstream society? How do we make sense of them and how can we account for their exemplary ability to guide the development of casino-cities?

\section{Upperworld and underworld in governance}

Popular thought during the 20th century was that the state governed the society and set the agenda for the development of society, independent of elite and ruling class interest (Hall and Ikenberry 1989; Skocpol 1979, 1992). Miliband (1969, p. 1) puts it best, "It was once believed, and perhaps believed even so today, that man live in the shadow of the state. Individual or group achievement is largely based on the support or sanctions by the state." If such popular thought persisted during the 20th century, then why did the state assume a subservient role in the cases of the developing Las Vegas and Macao during the 20th century, allowing Mr. Moe Dalitz and Dr. Stanley Ho to take the 'development' driving wheel and be hailed as 'King' of their respective empires? What exactly was its role in the formation of the casino-driven capitalist society? Against this wave of 'state-centric' theorists were the society-centric theorists, whose central tenets revolved around proving that the state was subservient to the control of the capitalist elites (Barrow 1993; Miliband 1977). The capitalist elites, in the tradition set out by Miliband's instrumentalist theory of the state (1969), challenged state-centric theorists by claiming that the state was not autonomous but rather an 'instrument' used by the elites to fulfill the interests of the capitalist class (Barrow 1993).

Yet, even in this intellectual battle with the state-centric theorists, society-centric theorists were 'upperworld-centric' and neglected actors of the 'underworld', i.e., not 
focusing on the relational powers of the elites in the underworld, such as organized crime kingpins. Previous studies have documented collusions between economic elites or political elites and organized crime groups (Hagedorn 2007; Simon 2008) in a wide variety of contexts, e.g., in a Chinese context (Lo 2010), Dutch context (Van Duyne 1993), and Indian context (Sreedhar 2013). As of the 20th century, organized crime groups have become increasingly 'inter-twined' into the webs of the political economy and become players in the 'upperworld'. Moreover, although not always, such collusions between the 'upperworld' and the 'underworld' also do occur in a triadic union of three; an economic-political-criminal nexus of sorts. This is particularly evident, albeit understudied, in recent cases around the world (see Chin 2003 for Taiwan; Patrucic 2014 for Montenegro; and the Research Institute for European and American Studies 2014 for Ukraine). This neglect not only significantly hampers our understanding of the behavioral characteristics and organization of the 'upperworld-underworld symbiose' (Venkatesh 2013) but also exposes our gross ignorance of the relation between this symbiose and our society. For example, and in line with another dimension of study the societycentric theorists oversaw, the dynamics of interaction among the ruling class and organized crime groups in the context of limited statehood. This is particularly important when considering aspects of governance, where, according to literature (Amsden and DiCaprio 2012; Risse 2013), non-state actors can overtake the state in functions of governance and assume responsibility in driving the development of a society with limited statehood, e.g., through non-hierarchical steering methods (Risse 2013). Not much is known nor conceptualized on the triadic union and its impact on areas of limited statehood, which is where this study serves to contribute to; i.e., by examining the influence these 'connected' economic elites had on their respective 'gaming empires' and the similar and divergent strategies they used to transform the lands. This study will conceptualize the investigated triadic union by using the term 'State-Crime Elites' to describe economic elites that strategically use relations with both statesmen and organized crime to pursue their interests. The term in no way suggests that the economic elite is a criminal himself/herself, unless specified in the analysis; rather, it places emphasis on the state-crime ties characteristic of the elite.

\section{About the study}

The theoretical light and perspective that the society-centric theorists sheds over examining the cases of Las Vegas and Macao proves as a suitable framework to adopt in this study. Following the theoretical footsteps set by Miliband (1969), Domhoff $(1990,1996)$, Mills (1956), i.e., studying relations and interactions between state and non-state actors as imperative to developing an understanding of how the society dominates the state, this study will begin with a historical perspective and then a relational perspective of the social actors in their juxtaposed time frame. This is ideal for two reasons: (1) The historical perspective can elucidate the background and development of the social actor, as well as shedding light on his/her 'enduring' connections; and (2) the relational perspective can elucidate 'key' social relationships formed during the chosen time frame which helped the social actor transform the land and build his/her empire. Moreover, it can help highlight strategies used with respect to his/her social network. Employing this framework to examine the cases of Las Vegas and Macao and their 'Kings', Mr. Morris 
Dalitz for 1940s-1980s and Dr. Stanley Ho for 1960s-2000s respectively, presents a unique opportunity to elucidate how the triadic union would govern or behave in a context of a developing society with limited statehood.

Taken together, results of this study have implications for academic and pragmatic endeavours. On the former end, this study would be significant for advancing our understanding of the roles of state and non-state actors in areas of limited statehood and developing economies. Furthermore, this study would contribute to our understanding of the relational dynamics and powers of non-state actors of the underworld, especially in colluding with economic and political elites; i.e., to form a triadic union. On the latter end, this study would be significant for advancing our understanding of casino-city developments; especially for demystifying previous thoughts on the development of Las Vegas and Macao and providing new insights to inform future endeavours in casino development. As the Global South continues to entertain possibilities of developing gaming-resorts or a casino-city for socio-economic growth, such as in Sri Lanka and Fiji, it is imperative to take a step back and acquire insights from the developmental histories of the 'proofs of concept' to inform future development. For example, insights on the challenges and opportunities of modelling after Las Vegas and Macao in the 21st century.

As the aforementioned questions set the fertile ground for a case-based historical sociological study, the following refined inquiries serve as the drivers of this research study:

RQ.1: What were the common and divergent patterns and strategies used between the two state-crime elites, Stanley Ho and Moe Dalitz?

RQ.2: What influence did the state-crime elites have on the development of their respective gaming hubs; Stanley Ho on Macao and Moe Dalitz on Las Vegas?

RQ.3: What can we learn from the development of Las Vegas and Macao and how is it relevant for aspiring casino-cities in the Global South?

\section{Methods}

The major research method employed is the comparative historical research method. Three research strategies are used: the case-based comparative strategy, documentary analysis, and social network analysis (ego-centered network).

\section{Case-based comparative strategy}

In light of the resemblances between the two cases, a comparative historical research method is ideal for comparing the two cases and understanding how the focal actors used their relations with state and criminal agents to shape their respective 'gaming empires'.

In comparative research, there are two strategies one can follow-Durkheim's variablebased strategy or Weber's case-based strategy (Ragin and Zaret 1983). Durkheim's variable-based strategy conceives explanations from comparing and "testing propositions about general patterns of relationships among abstract variables" (Ragin and Zaret 1983, p. 740). While it does have its advantages, it does not produce historically-grounded explanations and generalizations that accounts for causes and consequences of historical diversity (Ragin and Zaret 1983). Weber's case-based strategy retains contextual effects of historical origins as it encapsulates a variety of factors pertaining to investigated 
cases. This study will use the Weber case-based strategy. As such, the selected cases are defined as specific, empirical units.

\section{Documentary and archival records}

Primary sources of data are drawn from the analysis of official documents, archival collections, biographies, newspapers and periodicals, and reports from government bodies and universities. As previous criminologists have echoed (e.g., Varese 2012), studying criminals will always be a challenge; thus, reports from the FBI and other law enforcements that collect intelligence on the criminals would be of paramount importance. Secondary sources of data include books, dissertations, journal papers, magazine articles, and newspapers from online databases and libraries.

The documents used in this study can be retrieved from online databases, university libraries, the historical archives of Macao, and government bodies.

\section{Social network analysis (ego-centered network)}

In Social network analysis (SNA), a method used to study formal properties of social relations (Carrington and Scott 2011), there are two types of networks that can be made: complete networks and ego-centered networks (Martino and Spoto 2006). Complete networks involve mathematical models to analyze networks that can span cities and communities; whole networks from community data using quantitative methods (Carrington and Scott 2011). Popular among social movement studies, anthropological studies, historical studies, and even primary health studies, ego-centered networks revolves around understanding the relations between actors (alters) and the focal person (ego) through documentary sources, interviewing, surveying, and ethnographic investigations; personal networks from personal data using qualitative methods (Martino and Spoto 2006; Scott 2013). Thus, an ego-centered network is often smaller and more comprehensive than complete networks as it follows a focal individual and retains the contextual information surrounding his/her relations with the actors. One exemplary study is that by Wong (2009) on state-society relations in the Philippines. Although the network diagram was not included in the written piece, Wong (2009) was able to articulate comprehensive narratives which retained contextual backgrounds and elucidated relational dimensions of the ego with alters across time.

There are two broad strategies to specify the boundaries of networks: (1) Realist strategy. (2) Nominalist strategy (Scott 2013, p. 43). In the 'Realist' strategy, boundaries are thought to be real as they are informed by participants who perceive actual boundaries of social groups and organizations (Scott 2013). In the 'Nominalist' strategy, boundaries are formed by the researcher in categories based on analytical significance, e.g., relational properties and characteristics alters share with the focal actor (Scott 2013). This study will use the latter strategy as documentary sources cannot elucidate the 'true' nature of relations but can provide data which informs the formation of boundaries based on analytical significance, e.g., attributes, relational properties, and shared activities with potential members they share similar characteristics with (Martino and Spoto 2006).

This study will utilize ego-centered networks and the nominalist strategy to observe the selected social actors' networks and demonstrate how they tugged their state-crime 
'webs of significance' (Venkatesh 2013) to achieve their self-interest; thus, steering the development of Las Vegas and Macao to what we know of it today. The study will rely on primary and secondary sources of data to identify alters with ties to the focal actors, and use the collected data to inform the research of the overall social embeddedness of the focal actors' networks during their respective selected time frames. This is an acceptable data collection strategy in SNA for acquiring recorded data on social relations (Scott 2013, p. 41).

\section{Results and discussions}

\section{State-crime elites and their empires}

In understanding the ways of these powerful state-crime elites, it becomes apparent that the glorious transformation of the casino-cities was no accident; rather, it was engineered. As mentioned previously, before 1940s for Las Vegas and 1960s for Macao respectively, economic growth was not consistent and social stability was threatened. Moreover, both governments had no clear vision for socio-economic development and thus relied on interventions from the federal government or higher authorities and elites. In such cases of uncertainty and turmoil, Mills (1956, p. 27) argues that the "shifts in the structure of society open opportunities to various elites". Two groups of elites took the gambling concession before Dr. Ho, the Hou Heng Company in 1930 and the Tai Heng Company in 1937 (Pessanha 2012, p. 51), and various elites attempted to revive Las Vegas economy before Mr. Dalitz came into the picture. Yet, amidst their best efforts, they could not reinvent the society. It took economic elites with ties to criminals and statesmen to resuscitate the economy and transform the society.

\section{Morris 'Barney' Dalitz on Las Vegas (1940s-1980s)}

In building his empire in Las Vegas, Moe Dalitz used his ties to statesmen, public officials, business elites, and organized crime figures he had befriended throughout his life. During the 40 year period, Moe Dalitz strategically 'tugged' his ties to statesmen, such as Patrick McCarran (U.S. Senator from 1933-1954), Paul Laxalt (serving Las Vegas in government positions since the 1960s and U.S. Senator from 1974-1986), and the Reagan administration (1981-1989), and public officials, such as J. Edgar Hoover (1924-1972), largely taking advantage of Nevada's democratic electoral system for political king-making and the national law enforcement agencies for covering his tracks, and protecting his friends, to do his bidding in creating favorable political and economic conditions for the developing Las Vegas and evading the law. For example, with regards to protecting Moe Datliz and his organized crime affiliates in Las Vegas, J. Edgar Hoover helped steer FBI investigations clear from Moe Dalitz and his associates throughout his term as head of the FBI (Newton 2009), Pat McCarran helped during the 1950s Kefauver hearings, and Paul Laxalt helped in the 1970s-1980s with other federal investigations and silencing the media; with regards to earning more money by making void or reducing tax bills, Pat McCarran fought and negotiated the reduction of tax rate of federal tax bills from 10 to 0.25 \% (Las Vegas Review-Journal 1999a), and Paul Laxalt and the Reagan administration ensured that two federal tax bills were not passed (Newton 2009); with regards to protecting the 'shady' operations of his hotel-casinos, Grant Sawyer steered clear investigations into Desert-Inn in the 1960s (U.S. Federal Bureau of Investigation 
2001, p. 2586); and, with regards to gaining a stronger foothold in the government and appearing 'legitimate', Paul Laxalt and the Reagan administration appointed associates of Moe Dalitz in advisory positions for the Reagan administration (Newton 2009) and Moe Dalitz himself as a special assistant to Paul Laxalt after being elected to office (Orlando Sentinel 1987). The amounts that went into the pockets of the government and public officials were in the hundreds of thousands of dollars and it is not known just how many officials received payments, except that Moe had extensive ties which could help him 'cover' up anything and there were not many state or local politicians who were not financed by Moe Daltiz and his associates (Federal Bureau of Investigation 2001, pp. 184, 204). This 'strategic tugging' of social networks was possible because of the instrumental use of his hotel-casinos, largely Desert-Inn, which opened in the 1950s, and Stardust, which opened in the 1970s, and the Teamsters Union Pension Fund for political-king making, 'buying off' people, and an overall expansion of his legitimate portfolio of hotelcasinos in Las Vegas; which attracted more statesmen, economic elites, and public officials who would frequently patronize his establishments. Noting funds that flowed from Mr. Dalitz' establishments and related-operations-involving an legitimate economic elite 'front-man' for the hotel-casinos, e.g., Wilbur Clark (U.S. Federal Bureau of Investigation 2001, p. 219), illusory board of directors and stakeholders (U.S. Federal Bureau of Investigation 2001, p. 183), which concealed the identity Mr. Dalitz's mob associates, such as Morris Kleinman and Samuel Tucker (Gottdiener et al. 1999), and umbrella corporations, such as the Nevada Hotel Association, to get licenses from the Nevada Gaming Control Board-, to the pockets of public officials and statesmen, although all merely speculation, the U.S. Federal Bureau of Investigation recognized a 'reinforcing smokescreen' that Mr. Dalitz created. This 'smokescreen' concealed frequent, large-scale 'skimming' operations, mostly from Desert-Inn and Stardust, which helped finance subservient statesmen to office, 'buy' amicable law enforcement officials, 'hire' ignorant economic elites, and, taken together, 'secure' a development system that was impenetrable by internal and external interveners.

Behind the numerous 'fronts' Moe set up, Moe and his mobsters were involved in money laundering, political-king making, and decision-making for future investments and current affairs in Las Vegas. None of the 'front' men had any power, including the 'presidents' like Wilbur Clark (U.S. Federal Bureau of Investigation 2001, p. 149), and the statesmen, such as Pat McCarran, Paul Laxalt, and Grant Sawyer, all abided to Moe Dalitz's will. Since the 1960s, Moe and his associates would actively contribute to political campaigns and support political offices through the Nevada Hotel Association, specifically the Desert-Inn group and later Stardust group, by the aforementioned casino skimming operations (U.S. Federal Bureau of Investigation 2001, pp. 184, 112, 89). This lasted well onto the 1980s. Moreover, Moe and his associates were in frequent contact with financed statesmen and, no matter democrat or republican, Moe directed his associates to support any candidate who shared their vision and readily accepted advice on how to run the campaign to win (U.S. Federal Bureau of Investigation 2001, p. 89). But just how did they finance so many politicians and government officials? While the FBI acknowledged that most of the local politicians were supported by the Desert-Inn hotel group and other hotel-casino groups (U.S. Federal Bureau of Investigation 2001, p. 181), other politicians or related authority figures on a much higher 'playing field' 
often received their financial backings from the International Brotherhood of Teamsters (IBT), also called Teamsters Union. The IBT, a labor union group, was instrumental in Moe's building of the Las Vegas Empire. The Teamsters Pension Fund was often used as a back-up financial source for covering costs to expand when the earnings from the hotel-casinos could not cover it (U.S. Federal Bureau of Investigation 2001, p. 198). Similar to the umbrella corporations, IBT was under the strong influence of Moe Dalitz. Although Moe was not part of IBT, he was the most influential loaner for the Teamsters Pension Fund (Newton 2009). Teamster Union officials, such as 1957 Union President Jimmy 'Riddle' Hoffa and 1983 Union President Jackie Presser, were intricately linked with Moe's previous syndicate, i.e., the Cleveland Syndicate, and the organized crime group in Las Vegas, and they let Moe Dalitz and his associates use the Pension Fund as their private bank (Newton 2009).

In building his empire by wielding his legitimate and illegitimate instruments of power, Moe created a 'pro-gambling' atmosphere that not only influenced the political realm, but also the economic realm since the 1960s as Las Vegas officially recognized gaming as a legitimate business and had a clear direction of development-to be a casinodriven capitalist society (City of Las Vegas, n.d. 2015). In the 40 year time span Moe spent in Las Vegas, Moe also engaged in charitable works, e.g., funding the construction of a local hospital, and engaged in philanthropy, donating \$1.3 million dollars to various NGOs upon his death through a charitable trust (Las Vegas Review-Journal 1999a). He was awarded Humanitarian of the Year in 1976 and the Torch of Liberty Award in 1982 for his philanthropy and contribution to the society, particularly the gaming, recreation, and tourism sectors (Las Vegas Review-Journal 1999a). Even after his death in 1989, the pro-gambling atmosphere and image of world-class recreation he helped create encouraged secondary economic drivers to develop air transport infrastructure, conventions, and gaming-related services (Lang and Nicholas 2011).

\section{Dr. Stanley Ho Hung-Sun on Macao (1960s-2000s)}

In the 40 years spent to create his empire in Macao, Dr. Stanley Ho did not manipulate statesmen and public officials as much as Moe Dalitz, as the officials themselves wanted a "cozy relationship with the casino capitalist" (Lo 2007) and power to govern is often bestowed on economic elites by the colonial state (Risse 2013), e.g., through monopoly licenses. This is not to say however that Dr. Ho took a passive role during the decades he spent shaping Macao as a casino-city. Rather, during the 40 year period, Dr. Ho actively worked to cultivate and extend his social networks with political authorities and elites. For example, the gambling concession Dr. Ho won in 1961 and the extension of the concession in 1986 was helped by actively cultivating exchange relationships, ranging from providing advice on how to handle the Cultural Revolution to providing donations for development projects in Lisbon, with the Portuguese administration (McGivering 1999; Pina-Cabral 2002). Shifting political stances from anti-Japanese to pro-Japanese, Stanley Ho made his entrance into Macao in his early adulthood after halting his support for the resistance in Hong Kong and moving to work in the Macao Cooperative Company Limited (McGivering 1999). Securing a position in the company, and being a grand-niece of Sir Robert Hotung, opened a lot of doors for Ho to develop relations with the Portuguese government in Macao, the Japanese army, the wealthy Macanese, and later on the 
Chinese. It is during this war period that Ho, still in his early 20s, would accumulate his millions and accumulate social capital and extensive connections with resourceful businessmen and political authorities.

In 1961, realizing that the government-granted gaming concession in Macao was open, he joined with friends, Henry Fok, Teddy Yip, and Yip Hon, to form Sociedade de Turismo e Diversoes de Macao (Macao Tourism and Amusement Company) (STDM) to make the bid (McGivering 1999). STDM, with Dr. Ho holding the franchise name, won the bid in January 1st, 1962 and the building of Stanley Ho's Macao empire began (Welker 2005; Milgram and Lichtblau 2009). Having observed the dynamics and orientations between economic elites and statesmen in the colony since he first came to Macao, he capitalized on the opportunity to expand his influence and control beyond the gaming concession he was allotted. In the 1960s, upon receiving the monopoly, he started financing educational and religious institutions in Macao, introduced the first ferry (Hydrofoil) to the Hong Kong-Macao sea route, and became active in community works (Welker 2005). In the 1970s, the long awaited casino, the Hotel Lisboa opened, Shun Tak Enterprises was established, the Jetfoil (upgrade of Hyrdofoil) was introduced to shorten travel time between Hong Kong and Macao, and millions were being used to finance development projects (Welker 2005, p. 59). Hotel Lisboa, Dr. Ho's flagship hotel-casino, helped STDM make a net profit of over US \$20 million annually, with just under US \$5 million being allocated annually to community-development projects (Welker 2005, p. $50-51)$.

This revenue, for the state and Dr. Ho, skyrocketed in the 1980s when, in 1986, Dr. Ho's Grand Lisboa introduced VIP rooms, an exclusive gambling space catered for 'highrollers' (Wang and Eadington 2008). VIP rooms became core earners in casinos as a single VIP room of the Lisboa Casino could gross over half of the total revenue from Baccarat; Baccarat accounts for $65 \%$ of the total earnings in casino (Pinho 1987). This market brought in the majority of all gaming revenue in Macao (Pessanha 2012, p. 112). Of course, this also meant a lot more profit for STDM and Dr. Ho in particular, since he gained total control of STDM in the mid-1980s (Milgram and Lichtblau 2009).

But how was this 'VIP' system so successful? Later discovered, the VIP room attraction in the Grand Lisboa involved 'shady characters' and housed 'shady businesses', all of which Dr. Ho supposedly sanctioned because the VIP-room contractual system was not codified in law and thus STDM, with Dr. Ho as its leader, played the dominant role in establishing rules and managing the system (Wang and Eadington 2008). It was soon discovered that triad societies had been running the VIP rooms and junkets (Canadian Intelligence Resource Centre 2004). According to a special report by the State of New Jersey Department of Law and Public Safety (Milgram and Lichtblau 2009, p. 8-9), "The VIP room structure, introduced in 1986, facilitated the involvement of Asian Organized Crime in STDM casinos... The VIP rooms in the STDM casinos provided organized crime entry into the gaming market that it had previously lacked... STDM created a "lawless space" that allowed organized crime to gain a foothold in the Macao gaming industry." Having triad societies, such as $14 \mathrm{~K}$ or Wo On Lok, operate in one's establishments was a violation of Art 288 of the Penal code of the Macao gaming law, which provides for the offence of criminal association (Chan 2012, p. 127). While triad societies have always been notorious for their illegal gambling activities in Macao (Coates 1978), 
reports showed that Dr. Ho was and still is letting the organized criminal gangs "operate and thrive" within the premises of his casino establishments (Asia Pacific Post 2010; Milgram and Lichtblau 2009); engaging in loan sharking, prostitution, selling drugs, and money laundering operations as conduits within the casino premises (Canadian Intelligence Resource Centre 2004). However, despite sanctioning their operation, Dr. Ho denied any 'foul play' and simply stated in response to allegations: "to be associated with or to know someone is completely different (from being one)" (Pablo and AFP 2000, p. 2). Dr. Ho was not dismissing allegations he was affiliated with them, rather he dismissed allegations that he held triad membership. So, not being a triad member, how did Dr. Ho come to be acquainted with the triads? Dr. Ho had several ties to organized crimeaffiliates; that is, individuals with notable ties to members of organized crime groups, such as Mr. Yip Hon. In bidding for the concession, Dr. Ho chose Yip Hon as a partner specifically because "I needed someone who knew the inside of the business... who was a professional gambler" (McGivering 1999, p. 111). Yip Hon, as reports show, was not only a professional gambler who knew the insides of the casino business, but he also had a triad background (Asia Pacific Media Services Limited n.d. 2015).

While Dr. Ho was 'passing through the law' with questionable working arrangements of the VIP rooms, the state officials and public officials simply turned a blind eye. Macao was profiting from the VIP room high-rollers as it fueled the development of Macao's infrastructure and community. Thus, why would they stop Dr. Ho from doing something that benefits Macao, although it violates the law? In the late 1980s, due to the significant rise in revenues from the VIP rooms, Dr. Ho invested in TDM (Teledifusão de Macau), Macao's most popular television network, and the development of the Macau International Airport, which would open in 1995. Nearing the end of the century, the span of investments STDM had nearly covered the whole of Macao's economy (Pessanha 2012, p. 52). Dr. Ho's instrumental use of legitimate and illegitimate powers not only helped him engineer a casino-driven capitalist society, but also achieve prominence and recognition worldwide. All his work to improve the financial outlook and social stability of Macao got Ho, in the 1980s, to be elected to high positions in various associations, for example vice president of the Macau SAR Basic Law drafting committee and Standing Committee member of the National Committee of Chinese People's Political Consultative Conference, and earned him numerous accolades, including honorary doctorates and insignias (Welker 2005:59). Dr. Ho's personal net worth was estimated at US \$1 billion (Milgram and Lichtblau 2009).

\section{Similar and divergent strategies}

In building their empires, Mr. Dalitz and Dr. Ho shared similar 'game plans'; accumulate vast amounts of money and power, evade allegations of wrong-doings, and acquire the 'good guy' image. However, the strategies they employed to do each of those activities had more variation.

In regards to the similarities in their strategies, both state-crime elites used bridging social capital and linking social capital to accumulate money and power and to evade allegations. Moe Dalitz used bridging social capital to stay in touch with his out-of-state organized crime associates and business-affiliates out-of-the country. Mr. Dalitz, moreover, used linking social capital to be affiliated with higher political authorities, such as 
President Reagan, enabling access to greater power and resources. Likewise, Dr. Ho used bridging social capital to maintain relations with organized-crime affiliates, e.g., Yip Hon, and businessmen, e.g., Henry Fok, in Macao and overseas. Dr. Ho also used linking social capital to climb up the ladder, especially during the 1930s-1940s, when he socialized with various higher political authorities in the Portuguese and Japanese administration.

Another shared similarity is the decision to remain apolitical, which reflects their 'neutrality' and 'anything goes' attitude. Although both of them did hold positions in political and legal institutions, e.g., advisory positions, neither Mr. Dalitz nor Dr. Ho chose to run the race for political office because they already had access to state power, i.e., deriving power from the positions they held in political institutions and power bestowed by the state through relations with complacent statesmen or other equally high-positioned authorities. Especially for the case of Mr. Dalitz, this is unlike the results from Chin (2003) who found that organized crime figures turned legitimate businessmen would often run for office. A probable reason for the contrast may be due to the conditions in which the actors were in and their self-interests. In the case of Mr. Dalitz, there was no purpose for him to pursue political office because he was already involved in political king-making. Strategically, he would be able to achieve more as an economic elite, unbounded by institutional obligations of the office that would otherwise hamper his efforts.

Mr. Dalitz and Dr. Ho differed on three strategies used to build their empires. The first difference relates to their social network and their interaction with the key players in that network. The ego-centered networks of Mr. Dalitz (Fig. 1) and Dr. Ho (Fig. 2) was created using the primary and secondary data collected and analyzed in this study; perusing the relational dimensions and historical significance from the texts of alters to the focal actor to create the social categories of the ego-centered network. Alters were grouped into categories based on similar attributes, relational properties to the focal actor, and shared activities noted in the texts (Martino and Spoto 2006). The following categories were yielded for both actors: 'statesmen', 'members of organized crime', 'public officials', and 'businessmen. However, unique to Dr. Ho, an 'organized-crime affiliates' category was created. This joint category included alters such as Ip Hon, who served as both a connection to businessmen and a connection to the 'underworld'. While the texts elucidated direct relationships between the focal actors and the key players in each social category, the 'members of organized crime' category for Dr. Ho was indirect, running through the 'organized-crime affiliates' category. This sheds light to how Dr. Ho behaved socially when it came to the triad societies. Dr. Ho did not keep them close, socially and in business; rather, he used intermediaries to preserve his 'clean image', while also capitalizing on the capabilities of the triads in his businesses.

The second difference involved the need to shift identities, e.g., to cope with a change in political climate or evade the law. Mr. Dalitz, like his parents, frequently adopted pseudonyms, changed birth dates, residences, and occupations in official documents (U.S. Federal Bureau of Investigation 2001, p. 296). Moreover, Mr. Dalitz established a number of 'fronts' to protect himself, his income channel, and his investments. Mr. Dalitz almost always used 'front' men to hold positions of 'authority' in his many enterprises, always had income channels coming from legitimate enterprises to 'cover' his more lucrative 


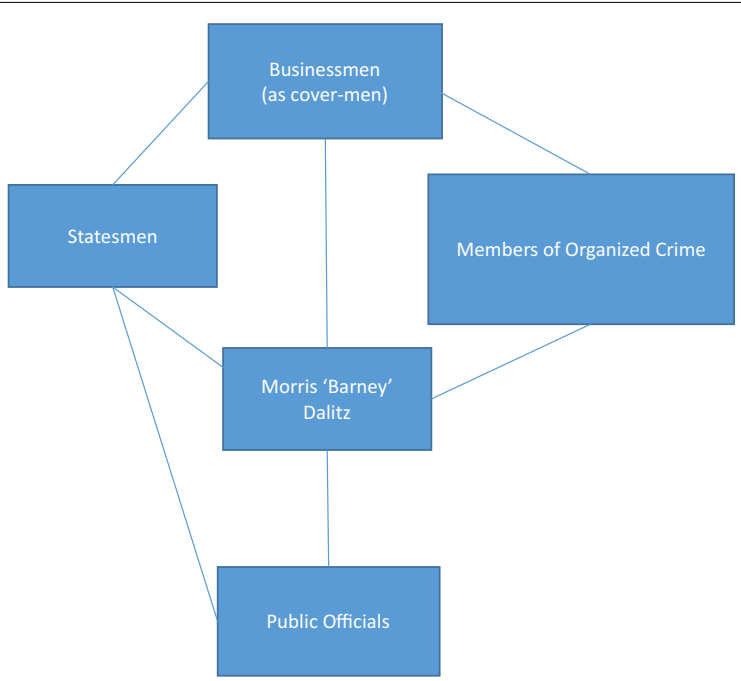

Fig. 1 Mr. Morris Dalitz network. The ego-network of Moe Dalitz with respect to the key groups Mr. Dalitz used to shape Las Vegas

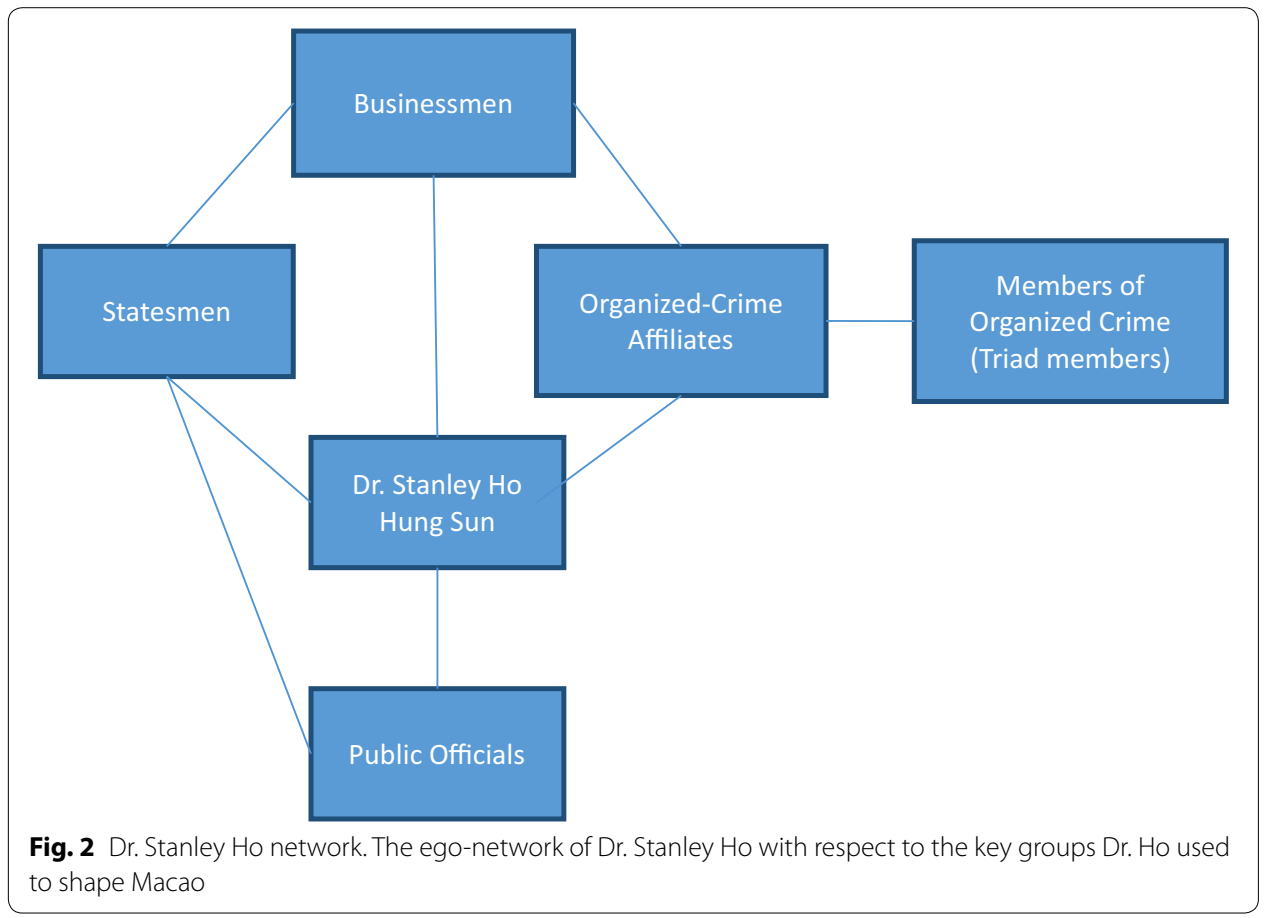

income channels coming from illegitimate or quasi-legitimate enterprises, and often established umbrella corporations to increase the red-tape and smokescreen over his illegitimate or quasi-legitimate enterprises. Dr. Ho, in contrast, used his ambiguous upbringing and Janus-like characteristics to dabble between allegiances and affiliations so that his allegiance and affiliation falls in line with the dominant political atmosphere. As put by Pina-Cabral (2002, p. 95), "When he obtained his first gambling contract (in 1961) Stanley Ho, the present-day magnate, was classified as Eurasian, being a nephew of Sir Robert Ho 
Tung and married to the daughter of a locally important Eurasian family (the Leitão family). Moreover, he was a figurehead for a syndicate in which he held only a minor share. Since then he has altered his importance within the syndicate as well as his favoured ethnic self-definition, insisting now on being considered Chinese". This is what Wong (2009) refers to as being a 'Chameleon'; the ability to "remain 'in position' during regime changes by changing their political appearance and affiliation flexibly" (Wong 2009, p. 61-62).

A third difference relates to how they handled allegations. Mr. Dalitz, with his vast influence over statesmen and public officials, was able to play down rumors and allegations of 'foul play' to the point where he was never convicted in his life, despite being under the spotlight for more than half his lifetime. Transitioning to a respected businessman in Las Vegas, illegalities had to be kept hidden, and Mr. Dalitz did just that by utilizing his ties to people of the 'underworld' and 'upperworld'. Dr. Ho, in contrast, did not have to deal with those problems. Dr. Ho had enough influence and control over major institutions, such as the media (TDM), to do whatever he wanted. While he could not stop international papers from printing accusations about his 'shady' businesses and ties, local investigations into his unsavory ties and questionable business ethics were deficient and no one dared to cross him during his time in power. Moreover, in the case of violating laws, administrators and public officials looked the other way, so there was no need to avoid allegations except when projected from the international community. Sutherland (1940, p. 8-9) puts it best, "Law is like a cobweb; it's made for flies and the smaller kinds of insects, so to speak, but lets the big bumblebees go through." In the cases of Mr. Dalitz and Dr. Ho, they had such a widespread influence and control over the development of Las Vegas and Macao respectively that they could pass through the law easily; effectively, being 'unchallenged' architects of their gaming empires.

\section{The nature of the state in a casino-driven capitalist society}

In investigating these two actors, it became apparent that the states in the respective territories assumed subservient roles to the ruling elite. Dr. Ho's unlawful practices in the casinos were not curtailed by orchestrated efforts of the authorities; rather, they turned a blind eye and watched state revenue from gaming increase. In the case of Mr. Dalitz, political corruption was rampant among statesmen as the mob financed anybody who had pro-gaming attitudes, not just McCarran, Sawyer, and Laxalt. In fact, most, if not all, state and national statesmen were directly or indirectly connected to the mob and Moe Dalitz, and were financed as they adhered to the interests of Moe Dalitz. As the state-crime elites assumed dominant positions in society, their influence, as seen from the results, was widespread and constructive.

This credits the instrumentalist Marxism tradition of the society-centric approach as the state was not autonomous and the statesmen were not independent of the schemes of the elites; rather they were 'instrumentally' used to adhere to the state-crime elite's 'master plan'. However, the results also expand the instrumentalist tradition as it rejects the idea that state domination is an act exclusively for 'upperworld' non-state actors of the ruling class. Both investigated actors dabbled between the two worlds and took advantage of the 'upperworld-underworld symbiose' to dominate governance; in the words of Risse (2013, p. 11), it was a case of "governance with government via networks" using non-hierarchical steering methods. The ruling class of the 'upperworld' was used 
by both actors, either as cover-men or for business expansionism, and the state was subservient to both actors. Moreover, organized crime groups played an important role in the focal actors' grand schemes and governance activities. In this sense, the state-crime elites created a secure environment that 'contained' their operations from any interventions; they had established both legitimate defenders, i.e., state actors, and illegitimate defenders, i.e., organized crime, to secure their casino-driven capitalist system.

\section{Challenges and opportunities for aspirers in the Global South}

Reflecting on the aforementioned results and discussions, it becomes clear that replicating the Las Vegas and Macao model in the 21st Century would simply not be possible. The development model referred to here is one that capitalizes on 'upperworld-underworld' relations. While indeed credit does go to Mr. Dalitz and Dr. Ho for recognizing the strength of the 'upperworld-underworld symbiose' and directing the symbiose towards fulfilling their 'master plans', the transformation of Las Vegas and Macao should be attributed to the development efforts of 'upperworld' state and non-state actors and 'underworld' non-state actors, i.e., organized crime groups, acting in a complementary fashion. In both cases examined, they served to defend and 'secure' the growth machine, as well as to channel flow of capital and resources from the 'upperworld' and 'underworld' towards development efforts. Perhaps, unsurprisingly, most, if not all, of the challenges faced in trying to replicate this 20th Century development model are related to the impact globalization has had on state and non-state actors, the global atmosphere, and the internal affairs of nation-states. It is not possible to replicate such a model because the very nature of the 'underworld' has changed, i.e., becoming less predictable with the rise of transnational organized crime and an enlarging 'shadow economy' [see Mandel (2010) for an in-depth discussion of how transnational organized crime, and the international political economy, has changed over time], the competition stiffened over gaming rights, and ideologues about casino-gaming in constant flux. This does not only make gaming development projects vulnerable, but the aforementioned challenges also have potential to misappropriate benefits accrued by a gaming-resort or casino-city (as an example, see the recent case of Canadian billionaire Michael DeGroote and organized crime involvement in his casino development venture).

Gaming resorts have proven themselves as economic drivers for socio-economic and community development, but key considerations must be in place to ensure its stability and protection. So, what are the elucidated opportunities evident from this study? In line with the framework used, we see the integral value of networking and instrumentally 'tugging' state-crime networks to fulfill goals and objectives otherwise not possible. It has potential to both make and break development. Thus, to protect gaming development projects, ensuring that the economic driver benefits the socioeconomic development of the community, we see the importance of establishing intelligence-gathering institutions and the importance of the executive handlings of a 'determined and unmoving' state over casino project developments and long-term maintenance. Before intelligence-related institutions can be established, it is important to ensure that casino development is within the interest of the state. Enduring support from the state is key to protecting economic drivers. If indeed casino development projects are in the interest of the state, and the state wants to accomplish the 
organizational goals set out, then intelligence must be valued and acted upon (Wilensky 1967).

While still a burgeoning practice and concept, since 1989, great hopes lies in it as the cold-war intelligence architecture begins to lose ground and the Global South starts to look to their own, rather than the US, for intelligence liaison and related-practices (Shiraz 2013). Casino developments, especially if in interest of the state, can provide an appropriate context for which to form an intelligence community that focuses more on 'internal' and 'domestic' protection of assets rather than 'confronting' and 'waging wars' against an elusive enemy, which is characteristic of the Global North's approach to using intelligence for supporting foreign policies (Shiraz 2013). Here, in the spirit of cooperation, alliance, and friendship, South-South intelligence liaison holds promise for two reasons: (1) There is a dire need for intelligence liaison knowing that casinos are used as 'points of transmission' for terrorist financing, money laundering, and the like of 'networked' activities that compromise the interests of the state; and (2) it would put SouthSouth cooperation on a new front that has not been embarked on before-intelligence cooperation for the purpose of protecting a niche economic driver, i.e., casino gaming resorts, by means of informing policy-making decisions and countering 'comprising' influences on casino-related projects.

\section{Conclusions}

In conclusion, this study has come to show that the emergence of Las Vegas and Macao was no ordinary development nor was it a crapshoot development; rather, it was the result of instrumentally concerted actions by economic elites with extensive and strategic ties to statesmen and organized crime groups. In the face of continuous failures by the state and economic elites to resuscitate the 'boom-crisis' economy of Las Vegas and Macao, it took non-state actors with intricate 'webs of significance' to state and criminal actors to govern the development of a society under limited statehood; transforming the lands into celebrated casino-cities.

Yet, in this realization, i.e., that the Las Vegas and Macao development models are not ideal in the 21st Century, a number of intriguing insights are also gained. Drawing from these two cases, opportunities for closer South-South cooperation and alliancebuilding, especially on the fronts of intelligence-sharing and governance bodies, are elucidated. The race for casino-cities in a highly connected world gives rising importance to the need for a secure environment that can preserve the interests of the state; be it core economic drivers, such as developing gaming-resorts, or other interests of the state. Adhering to the spirit of Asia-Africa cooperation, in the context of intelligence-sharing alliances and governance bodies for protecting the development of casino-resorts and casino-cities, trust and respect for one another is a necessity in this time of heightened global uncertainty and change. Only then, can the Global South truly rise together and live up to its principles. 
Received: 9 August 2015 Accepted: 24 November 2015

Published online: 09 December 2015

\section{References}

Amsden, A.H., and A. DiCaprio. 2012. Understanding the dynamics of elite behavior in a development context. In The roles of elites in economic development, ed. A.H. Amsden, A. DiCaprio, and J.A. Robinson, 351-361. Oxford: Oxford University Press.

Asia Pacific Media Services Limited. n.d. 2015. Stanley Ho's Luck turns Sour. Available from http://www.asiapacificms.com/ articles/luck_turns_sour/.

Asia Pacific Post. 2010, April 28th. An alliance of the rich, the powerful and the suspicious. Available from http://www. asianpacificpost.com/article/3888-alliance-rich-powerful-and-suspicious.html.

Barrow, C. 1993. Critical theories of the state: Marxist, Neo-Marxist, Post-Marxist. Wisconsin: The Wisconsin Press.

Carrington, P.J., and J. Scott. 2011. Introduction. In SAGE handbook of social network analysis, ed. J. Scott, and P.J. Carrington, 1-8. London: SAGE Publications Ltd.

Canadian Intelligence Resource Center. 2004, July 22nd. Casino connections part 2-Stanley Ho's house of cards. Available from http://circ.jmellon.com/docs/view.asp?id=657.

Chan, P.M. 2012. Casino Crimes in Macau. In Studies on Macau Gaming Law, ed. S. Mancuso, 173-220. China: LexisNexis.

Chin, K. 2003. Heijin: organized crime, business, and politics in Taiwan. London: M.E. Sharpe.

City of Las Vegas. n.d. History. Available from http://www.lasvegasnevada.gov/factsstatistics/history.htm.

Coates, A. 1978. A Macao narrative. Hong Kong: Heinemann Educational Books.

Domhoff, G. 1996. State autonomy or class dominance: case studied on policy making in America. New York: Aldine De Gruyter.

Domhoff, G. 1990. The power elite and the state: how policy is made in America. New York: Aldine De Gruyter.

Fu, A., and M. Murray. 2014. Glorified fantasies and masterpieces of deception on importing Las Vegas into the ${ }^{\prime} \mathrm{New}$ South Africa'. International Journal of Urban and Regional Research 38(3): 843-863.

Global Market Advisors. 2015. Casino and the city: a white paper on the history of casino development in cities, past and current trends, and recommendations for future development. Available from http://globalmarketadvisors.com/ wp-content/uploads/2015/04/Casinos-and-the-City-A-White-Paper-On-Urban-Casino-Development.pdf.

Gottdiener, M., C. Collins, and D. Dicken. 1999. Las Vegas: the social production of an all-American city. Oxford: Blackwell.

Gunn, G.C. 1995. Macau, 1578-1999. An economic and political history. Historical Archives of Macao Books Catalogue (Call number: LR.0721). Historical Archives of Macao, Macao.

Hagedorn, J. 2007. Gangs in the global city: alternatives to traditional criminology. Illinois: University of Illinois Press.

Hall, J., and G. Ikenberry. 1989. The state. Minnesota: University of Minnesota Press.

Lang, R., and C. Nicholas. 2011. The world city of gaming. UNLV Gaming Research and Review Journal 15(2): 3-4.

Las Vegas Review-Journal. 1999a, February 7th. Moe Dalitz. Available from http://www.reviewjournal.com/news/ moe-dalitz.

Lo, S. 2007. Casino politics, organized crime and the post-colonial state in Macau. Journal of Contemporary China 14(43): 207-224.

Lo, T. 2010. Beyond social capital: triad organized crime in Hong Kong and China. British Journal of Criminology 50(5): $851-872$.

Mandel, R. 2010. Dark Logic: transnational criminal tactics and global security (Stanford Security Studies). California: Stanford University Press.

Martino, F., and A. Spoto. 2006. Social network analysis: a brief theoretical review and further perspectives in the study of Information Technology. PsychNology Journal 4(1): 53-86.

McGivering, J. 1999. Macao remembers. Oxford: Oxford University Press.

Milgram, A., and J. Lichtblau. 2009. Special report of the Division of Gaming Enforcement to the casino control commission on its investigation of MGM Mirage's joint venture with Pansy Ho in Macau, Special Administrative Region, People's Republic of China. Available from http://www.state.nj.us/casinos/home/info/docs/MGM/dge_\%20report_ redacted.pdf.

Miliband, R. 1969. The state in capitalist society. New York: Basic Books.

Miliband, R. 1977. Marxism and politics. Oxford: Oxford University Press.

Mills, C.W. 1956. The power elite. New York: Oxford University Press.

Newton, M. 2009. Mr. Mob: the life and crimes of Moe Dalitz. North Carolina: McFarland and Company.

Orlando Sentinel. 1987. Laxalt Denies Paper's Story Linking Him with Mobster. Available from http://articles.orlandosentinel.com/1987-06-18/news/0130440204_1_laxalt-organized-crime-dalitz.

Pablo, C., and AFP. 2000. House Probe an Insult-Stanley Ho. The Daily Inquirer: 2.

Patrucic, M. 2014. Montenegro: Prime Minister's Family Bank Catered to Organized Crime. Available from https://reportingproject.net/unholy-alliances/prime-ministers-family-bank-catered-to-organized-crime.html.

Pessanha, L. 2012. Gaming concessions in Macau. In Studies on Macau gaming law, ed. S. Mancuso, 47-124. China: LexisNexis.

Pina-Cabral, J. 2002. Between China and Europe: person, culture, and emotion in Macao. London: Continuum.

Pinho, A. 1987. Gambling in Macau. In Macau: city of commerce and culture, ed. Cremer RD, 7-21. Historical archives of Macao books catalogue (Call number: AH 10093). Historical Archives of Macao, Macao.

Ragin, C., and D. Zaret. 1983. Theory and method in comparative research: two strategies. Social Forces 61(3): 731-751.

Rephann, T.J., M. Dalton, A. Stair, and A. Isserman. 1997. Casino gambling as an economic development strategy. Tourism Economics 3(2): 161-183.

Research Institute for European and American Studies. 2014. Ukraine's Anti-Soviet Euro Revolution. Available from http:// www.taraskuzio.net/euromaidan_files/8.pdf. 
Risse, T. 2013. Governance without a state? policies and politics in areas of limited statehood. New York: Columbia University Press.

Scott, J. 2013. Social network analysis, 3rd ed. London: SAGE Publications Ltd.

Shiraz, Z. 2013. Drugs and dirty wars: intelligence cooperation in the Global South. Third World Quarterly 34(10): $1749-1766$.

Simon, D. 2008. Elite deviance, 9th ed. New York: Pearson Education Inc.

Skocpol, T. 1979. States and social revolutions: a comparative analysis of France, Russia, and China. Cambridge: Cambridge University Press.

Skocpol, T. 1992. Protecting soldiers and mothers. Cambridge: Harvard University Press.

Sreedhar, A. 2013. My days in the underworld: rise of the Bangalore Mafia. India: Westland Ltd.

Sutherland, E.H. 1940. White-collar criminality. American Sociological Review 5(1): 1-12.

Thompson, W.N. 1998. Casinos de Juegos del Mundo: a survey of world gambling. The ANNALS of the American Academy of Political and Social Science 556(1): 11-21.

U.S. Federal Bureau of Investigation. 2001. Morris B. Dalitz. Progressive Management, New Jersey. Retrieved from database (20th Century FBI Files: Declassified Documents from the Federal Bureau of Investigation (FBI). Mafia, Organized Crime, and Gangsters (Volume 10), CD-ROM, 2001 release). ISBN: 1-931828-01-6.

Van Duyne, P. 1993. Organized crime and business crime-enterprises in the Netherlands. Crime, Law, and Social Change 19(2): 103-142.

Varese, F. 2012. How Mafias take advantage of globalization: the Russian Mafia in Italy. British Journal of Criminology 52(2): 235-253.

Venkatesh, S. 2013. Floating city: a rogue sociologist lost and found in New York's underground economy. New York: The Penguin Press.

Vlcek, W. 2015. Taking other people's money: development and the political economy of Asian casinos. The Pacific Review 28(3): 323-345.

Wang, W., and W.R. Eadington. 2008. The VIP-room contractual system and Macao's traditional casino industry. China: An International Journal 6(2): 237-260.

Welker, J. 2005. The New Macau. Historical Archives of Macao Books Catalogue (Call number: AH 10663). Historical Archives of Macao, Macao.

Wilensky, H.L. 1967. Organizational intelligence: knowledge and policy in government and industry. New York: Basic Books. Wong, P.N. 2009. In search of the state-in-society: reconceiving Philippine political development, 1946-2002. Germany: VDM Verlag Dr. Müller Aktiengesellschaft \& Co. KG, Saarbrücken.

\section{Submit your manuscript to a SpringerOpen ${ }^{\circ}$ journal and benefit from:}

- Convenient online submission

- Rigorous peer review

- Immediate publication on acceptance

- Open access: articles freely available online

- High visibility within the field

- Retaining the copyright to your article

Submit your next manuscript at $\boldsymbol{\nabla}$ springeropen.com 